\title{
Implementasi Pemanfaatan Web Service Pada Layanan Puskesmas Kabupaten Musi Banyuasin
}

\author{
Hesa Bimantara ${ }^{1}$, Hutrianto*2 \\ ${ }^{1,2}$ Informatics Department, Bina Darma University, Palembang, Indonesia \\ Email: hesabimantara09@gmail.com¹, hutrianto@binadarma.ac.id²
}

\begin{abstract}
Information technology is currently developing very rapidly and affects various aspects of life and the profession, one of which is in the field of health services, in various places, be it health centers, clinics or hospitals. The party will definitely record in detail the medical results of someone who is receiving treatment, that is what is called a medical record. Some of the puskesmas in the Musi Banyuasin district, especially the Tanah Abang puskesmas, are located in the district. Batanghari leko still doesn't have a decentralized database which means it doesn't have centralized storage. Web service itself is a liaison that allows various systems to communicate without being affected by platform differences. Web services also provide existing services on the old system to be able to communicate with the new system without making changes to both. This study was simulated at Tanah Abang Public Health Center and Bukit Selabu Public Health Center in the Musi Banyuasin Regency with the aim of making it easier for doctors and health centers to obtain patient medical records in the shortest time.
\end{abstract}

Keywords: Web Service, Medical Records, Puskesmas, Rapid Application Development, Curl.

\section{PENDAHULUAN}

Rekam medis adalah sebuah data yang bersifat sangat pribadi dan menjadi salah satu informasi penting yang wajib menyertai seseorang kemanapun dia pergi, atau sering disebut sebagai pencatatan data Riwayat Kesehatan pasien, Kegunaan dari rekam medis diantaranya adalah sebagai alat komunikasi antara dokter dan tenaga Kesehatan lainnya yang ikut ambil bagian dalam memberikan pelayanan, pengobatan dan perawatan kepada pasien dan juga sebagai bukti atas segala tindakan pelayanan, perkembangan penyakit dan pengobatan sekama pasien berkunjung atau dirawat di fasilitas pelayanan Kesehatan. (Santoso and Amalia, 2019).

Di kabupaten musi banyuasin sebagian puskesmas sudah memakai rekam 


\section{Journal of Software Engineering Ampera}

Vol. 1, No. 2, June 2021 e-ISSN: 2775-2488

https://journal-computing.org/index.php/journal-sea/index

medis berbasis web yang datanya tersimpan ke database, akan tetapi masih belum memiliki database terpusat sehingga antar puskesmas masih belum bisa saling bertukar informasi rekam medis pasien jika dibutuhkan khususnya dipuskesmas tanah abang yang berada dikecamatan Batanghari leko, maka diperlukan layanan web service untuk mempermudah pertukaran data rekam medis antar puskesmas.

Menurut Kreger (2001), web service merupakan sebuah antarmuka yang menggambarkan sekumpulan method atau operasi yang dapat diakses melalui pesan standar XML. Web service umumnya digunakan sebagai website yang melayani aplikasi-aplikasi independent yang mendukung aplikasi tersebut untuk kebutuhan integrasi data atau bertukar informasi. Web service menyimpan data informasi dalam format XML dan JavaScript Object Notation (JSON), sehingga data dapat diakses oleh sistem lain walaupun berbeda platfrom, sistem informasi, maupun compiler. (Santoso and Amalia, 2019), Dengan adanya web service maka setiap perusahaan atau instansi dapat berhubungan langsung dengan perusahaan atau instansi lain, hal ini sangat membantu perusahaan/instansi dalam pelayanan untuk suatu informasi.

\section{METODOLOGI PENELITIAN}

\subsection{Metode Pengembangan Sistem}

Metode pengembangan sistem yang digunakan pada penelitian pemanfaatan web service pada layanan puskesmas kabupaten musi banyuasin ini adalah metode RAD (Rapid Application Development), ada empat tahapan dalam model RAD. Berikut tahapan-tahapan dalam RAD model:

\subsubsection{Requirements Planning (Rencana Kebutuhan)}

Pada fase rencana kebutuhan ini, dilakukan analisa kebutuhan masalah untuk proses pembangunan sistem web service, mengidentifikasi masalah serta memberikan solusi untuk permasalahan tersebut.

\subsubsection{Design Workshop (Proses Desain)}

Tahapan ini terdiri atas analisa perancangan design antar muka aplikasi sesuai dengan informasi yang ada dalam pengumpulan data, dan ditahapan ini juga penulis melakukan representasi visual dari desain dan alur kerja terhadap pengguna. Kebutuhan dari pengguna atau bisa disebut aktor yang akan melakukan interaksi dengan sistem yaitu merancang antar muka admin sebagai penginput data dokter dan poli, loket sebagai tempat 


\section{Journal of Software Engineering Ampera}

Vol. 1, No. 2, June 2021 e-ISSN: 2775-2488

https://journal-computing.org/index.php/journal-sea/index

pendaftaran bagi pasien dan selanjutnya data diterima oleh dokter sesuai pendaftaran. Untuk diagramnya pada gambar berikut ini:

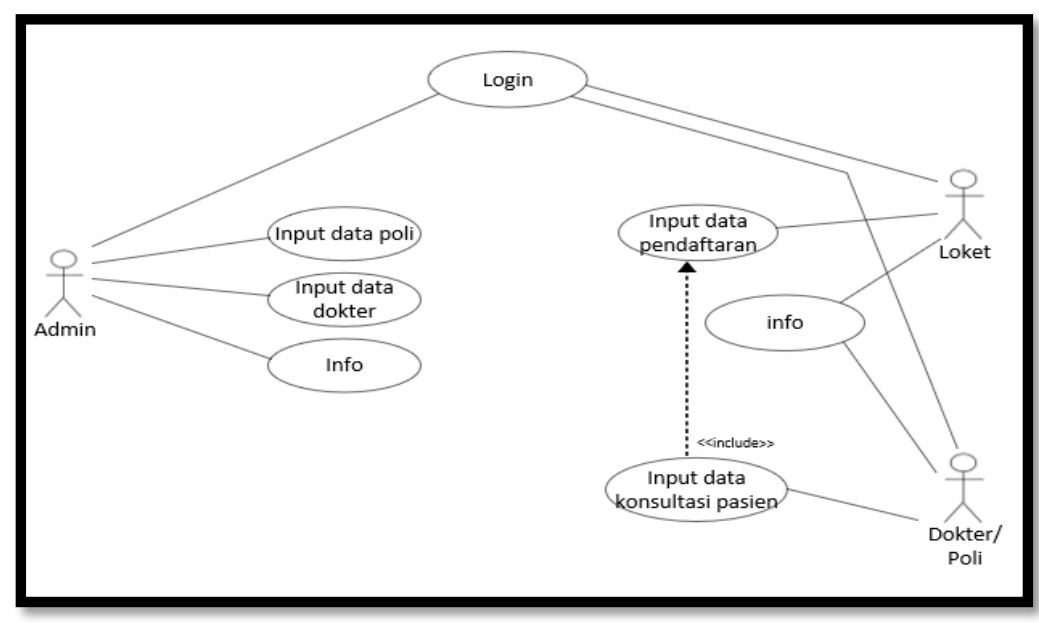

Gambar 1 Use Case Diagram Website puskesmas

Pada gambar 1 kita bisa lihat untuk aktor admin terdapat beberapa menu yakni admin bisa menginput data poli dan dokter ini artinya admin bisa mengedit informasi poli dan data dokter, serta bisa melihat info yang berisikan tentang berapa pasien yang berobat, siapa saja dan informasi mengenai pasien tersebut.

Untuk aktor loket, diberikan tugas untuk mendaftarkan pasien yang ingin berobat disistem yakni mencatat nomor urut pendaftaran pasien, nama lengkap, alamat, serta keluhan sehinga bisa menentukan pasien akan diarahkan kepoli bagian mana dan diupload disistem. Untuk aktor poli/dokter, mereka menerima inputan pendaftaran dari bagian aktor pendaftaran disistem sehingga aktor poli/dokter bisa menindaklanjuti pasien yang ingin berobat, serta dokter bisa menganalisa dan mencatat rekam medis pasien disistem dan mengupload nya.

\subsubsection{Kontruksi}

Pada fase ini setiap desain yang diciptakan dalam fase perancangan design selanjutnya ditingkatan untuk melakukan pengkodingan system. Pengkodingan program merupakan tahapan penerjemah desain sistem yang telah dibuat kedalam bentuk perintah-perintah yang dimengerti computer. 


\section{Journal of Software Engineering Ampera}

Vol. 1, No. 2, June 2021 e-ISSN: 2775-2488

https://journal-computing.org/index.php/journal-sea/index

\subsubsection{Implementation (Implementasi)}

Pada tahapan implementasi ini, system analyst dan para user menguji coba sistem, baru kemudian diperkenalkan kepada organisasi

\section{HASIL DAN PEMBAHASAN}

Pada tahapan ini akan dibangun sistem web service yang terhubung diantara dua puskesmas, menggunakan metode pengembangan sistem RAD ini terdapat dua tahapan lanjutan yaitu:

1. Fase kontruksi

2. Fase pelaksanaan

\subsection{Fase Kontruksi}

Pada tahapan ini dilakukan pembangungan terhadap sistem web service yang akan dibangun didalam website puskesmas tanah abang dan puskesmas bukit selabu, sebagai simulasi website untuk kedua puskesmas tersebut akan dibangun menggunakan seperangkat web server xampp yang mencakup apache, php myadmin, my sql.

\section{A. Pemrograman}

Tahap pemrograman ini akan dilakukan pengkodingan terhadap rancangan yang telah dibuat sebelumnya menggunakan bahasa pemrograman yang telah ditentukan, untuk bahasa pemrograman yang digunakan dalam membangun website puskesmas tanah abang dan puskesmas bukit selabu ini menggunakan bahasa pemrograman php sedangkan untuk web service menggunakan curl sebagai library nya serta sarana pendukung lainnya.

\subsubsection{Tampilan Halaman Menu Login}

Tampilan halaman menu login adalah halaman pertama kali ketika kita akan hendak masuk kedalam website, halaman login ini merupakan tampilan halaman login dari puskesmas tanah abang dan puskesmas bukit selabu, walau tempat login nya berbeda untuk kedua puskesmas tersebut akan tetapi untuk tampilannya sama persis, dan walau ditempat login yang sama baik itu admin, loket dan poli memiliki User ID dan password yang berbeda sehingga admin, loket dan poli bisa masuk ke dalam halaman mereka masing-masing menggunakan halaman login ini, berikut adalah tampilannya: 


\section{Journal of Software Engineering Ampera}

Vol. 1, No. 2, June 2021 e-ISSN: 2775-2488

https://journal-computing.org/index.php/journal-sea/index

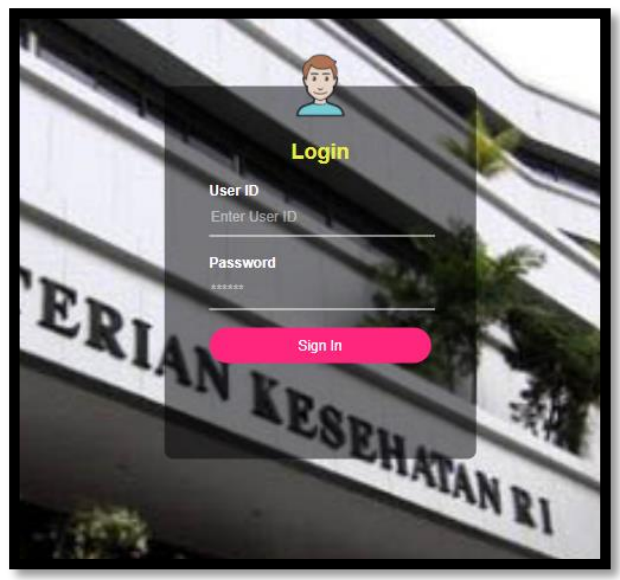

Gambar 2 Tampilan Halaman Menu Login

\subsubsection{Tampilan Halaman Menu Utama Admin}

Tampilan halaman menu utama admin ini adalah ketika admin sudah login menggunakan User ID dan password yang dikhususkan untuk admin, ketika masuk menu utama akan ada beberapa menu pilihan seperti input data pada poli, dokter dan juga bagian informasi seperti daftar dokter, daftar poli, seluruh pendaftaran, berdasarkan poli dan periode pendaftaran. berikut adalah tampilan halamannya:

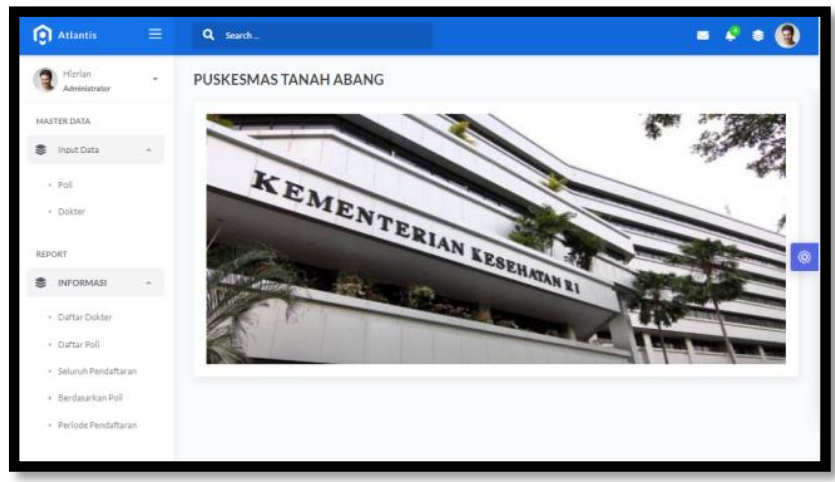

Gambar 3 Tampilan Halaman Menu Utama Admin

\subsubsection{Tampilan Halaman Admin Input Data Poli}

Tampilan halaman admin input data poli ini adalah ketika admin memilih menu input data pada poli, dihalaman ini admin bisa menambahkan data poli baru atau mengedit data poli yang sudah ada, dan juga admin bisa 


\section{Journal of Software Engineering Ampera}

Vol. 1, No. 2, June 2021 e-ISSN: 2775-2488

https://journal-computing.org/index.php/journal-sea/index

mengisi data poli yakni berupa User ID dan password yang digunakan oleh user poli untuk login ke halaman poli mereka masing-masing. Berikut adalah tampilan halamannya:

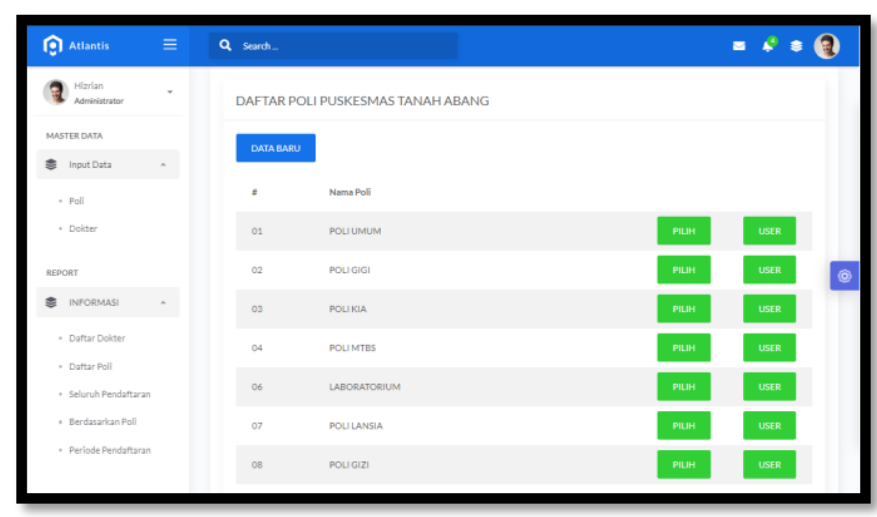

Gambar 4 Tampilan Halaman Admin Input Data Poli

\subsubsection{Tampilan Halaman Admin Input Data Dokter}

Tampilan halaman admin input data dokter adalah halaman dimana admin bisa menginput data dokter yang baru atau mengedit data dokter yang sudah ada, dihalaman ini terdapat nama dokter, alamat dokter, no telpon dokter dan bagian poli dokter tersebut, berikut adalah tampilan halamannya:

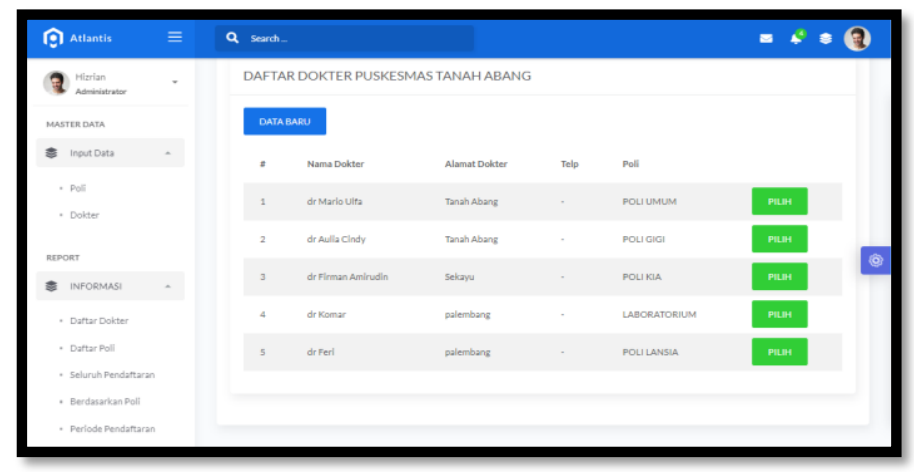

Gambar 5 Tampilan Halaman Admin Input Data Dokter

\subsubsection{Tampilan Halaman Menu Utama Loket}

Ketika user loket telah login menggunakan Use ID dan password yang diperuntukkan untuk bagian loket maka akan masuk kehalaman menu 


\section{Journal of Software Engineering Ampera}

Vol. 1, No. 2, June 2021 e-ISSN: 2775-2488

https://journal-computing.org/index.php/journal-sea/index

utama loket, dihalaman ini terdapat menu input data berupa pendaftaran, berikut tampilan halamannya:

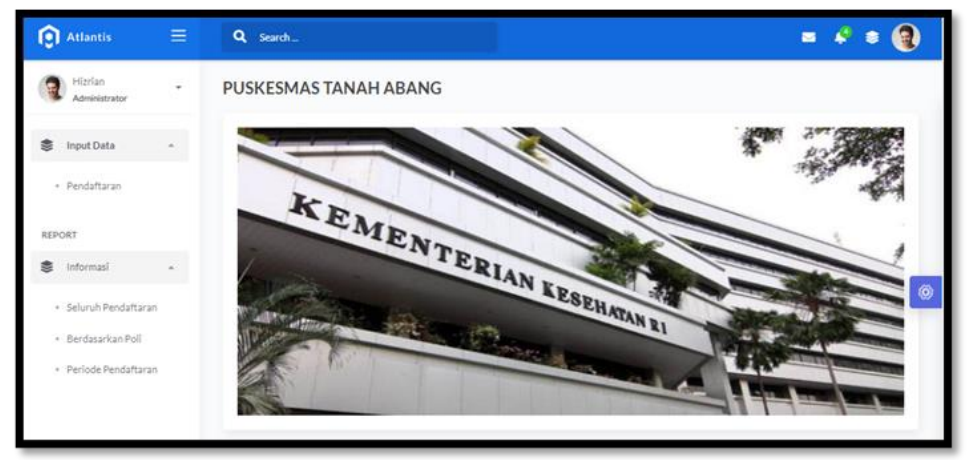

Gambar 6 Tampilan Halaman Menu Utama Loket

\subsubsection{Tampilan Halaman Loket Pendaftaran}

halaman loket ini meliputi pendaftaran pasien berupa form pendaftaran yang harus diisi agar data pasien diteruskan kepoli tujuan. Berikut adalah tampilannya:

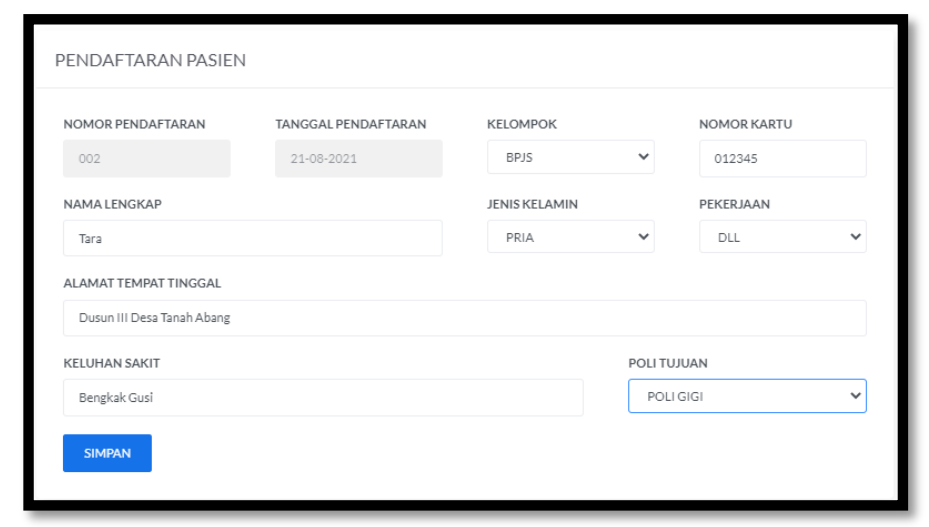

Gambar 7 Tampilan Halaman Pendaftaran Pasien Baru

\subsubsection{Tampilan Halaman Menu Utama Poli}

Sama seperti bagian admin dan loket, untuk login ke halaman poli ini harus menggunakan User ID dan password yang telah dibuat oleh admin dan untuk masing-masing poli pun memiliki user ID dan password yang berbeda, hal ini dikarena kan ketika pasien selesai mendaftar dan data sudah diproses maka data pasien tersebut akan menuju ke poli tujuan 


\section{Journal of Software Engineering Ampera}

Vol. 1, No. 2, June 2021 e-ISSN: 2775-2488

https://journal-computing.org/index.php/journal-sea/index

pasien masing-masing, jadi data pasien antar poli tidak bercampur. Dihalaman poli ini terdapat beberapa menu yakni Input Konsultasi dan menu informasi yang sama persis seperti dibagian admin dan loket, berikut adalah tampilannya:

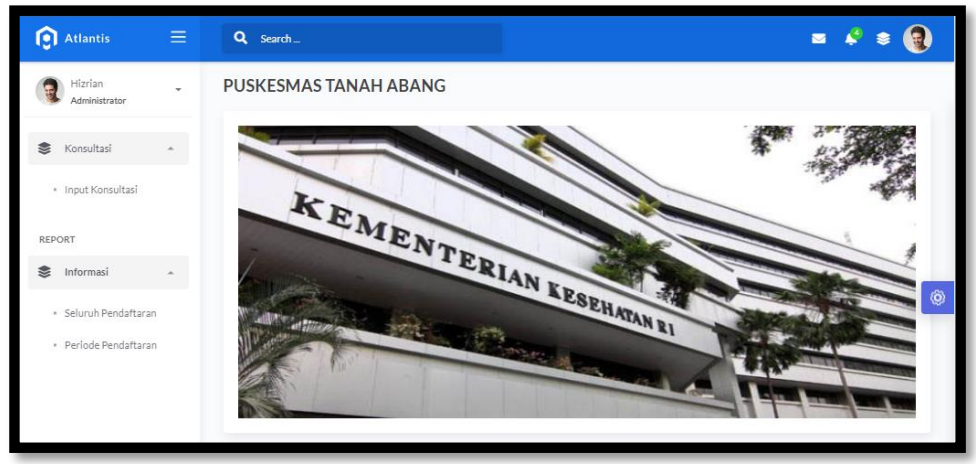

Gambar 8 Tampilan Halaman Menu Utama Poli

\subsubsection{Tampilan Halaman Poli Input Konsultasi}

Dihalaman ini menampilkan data dari pasien yang sudah mendaftar diloket, sebagai contoh ketika pasien mendaftar dengan tujuan poli gigi maka pada halaman input konsultasi pol igigi akan muncul data pasien tersebut, begitu pun dengan poli yang lain. Tampilan halaman poli input konsultasi sebagai berikut:

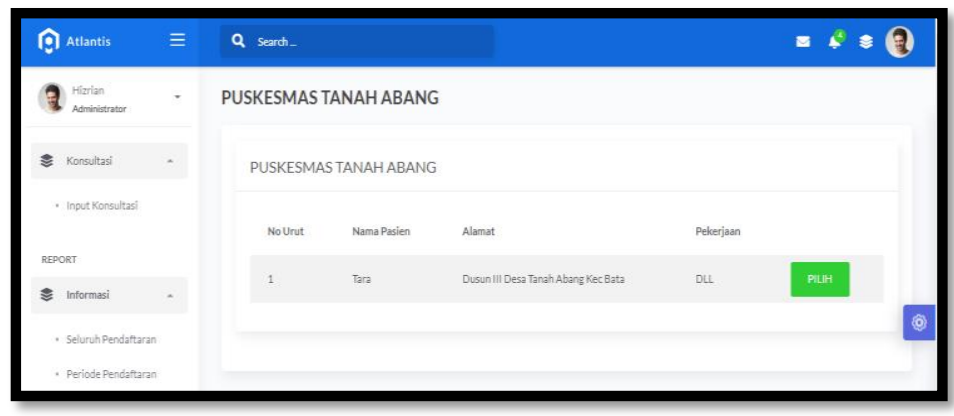

Gambar 9 Tampilan Halaman Poli Input Konsultasi

\subsubsection{Menu Pencarian Rekam Medis}

Selanjutnya adalah menu rekam medik, dimenu rekam medik ini kita bisa mencari data rekam medik pasien yang berobat dipuskesmas sebelumnya, 


\section{Journal of Software Engineering Ampera}

Vol. 1, No. 2, June 2021 e-ISSN: 2775-2488

https://journal-computing.org/index.php/journal-sea/index

rekam medik tersebut hanya menampilkan data pasien berupa no rekam medik, tanggal rekam medik, nama pasien, alamat dan poli tujuan pasien di puskesmas sebelumnya. Sebagai contoh ketika kita memilih mencari rekam medik di puskesmas bukit selabu dan klik tombol tampilkan, maka akan keluar semua data pasien yang berobat dipuskesmas bukit selabu kemudian kita tinggal mencari nama pasien di kolom pencarian dan data rekam medik dipuskesmas sebelumnya akan keluar, berikut adalah tampilan dari menu rekam medik:

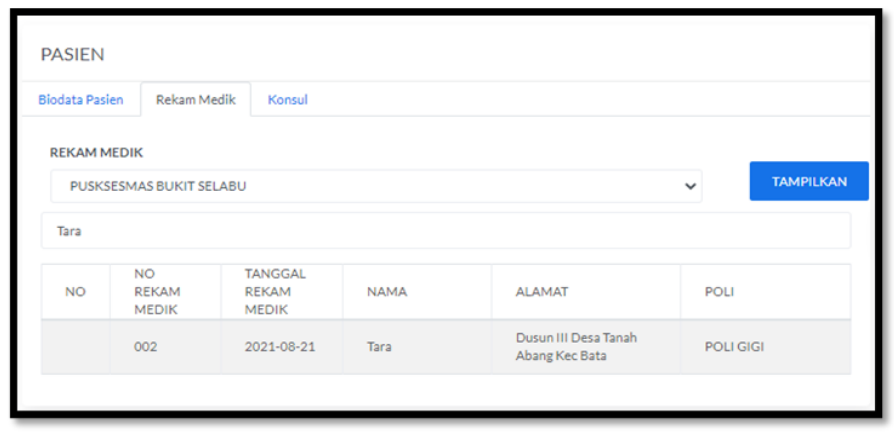

Gambar 10 Tampilan Menu Search Rekam Medis

\section{B. Fase Pelaksanaan}

Pada fase pelaksanaan ini penulis akan menguji sistem yang telah dibangun menggunakan blackbox testing, pengujian menggunakan blackbox testing ini dilakukan oleh user untuk melihat apakah ada kendala dari program yang telah dibangun.

\subsubsection{Pengujian Halaman Login Puskesmas}

Rencana pengujian halaman login puskesmas yang terdapat pada website puskesmas tanah abang dan puskesmas bukit selabu akan dilakukan berdasarkan tabel berikut ini:

Tabel 1 Pengujian Halaman Login Puskesmas

\begin{tabular}{|l|l|l|l|l|l|}
\hline No & $\begin{array}{c}\text { Item yang } \\
\text { diuji }\end{array}$ & \multicolumn{1}{c|}{$\begin{array}{c}\text { Cara } \\
\text { pengujian }\end{array}$} & $\begin{array}{c}\text { Hasil yang } \\
\text { diharapkan }\end{array}$ & \multicolumn{1}{|c|}{$\begin{array}{c}\text { Hasil } \\
\text { pengujian }\end{array}$} & keterangan \\
\hline 1 & Halaman & User & Menampilkan & Sesuai \\
memasukan & halaman & Berhasil \\
& login & $\begin{array}{l}\text { User ID dan } \\
\text { password } \\
\text { kemudian }\end{array}$ & $\begin{array}{l}\text { utama baik } \\
\text { itu halaman } \\
\text { admin, loket }\end{array}$ & & \\
& & & & \\
\hline
\end{tabular}




\section{Journal of Software Engineering Ampera}

Vol. 1, No. 2, June 2021 e-ISSN: 2775-2488

https://journal-computing.org/index.php/journal-sea/index

\begin{tabular}{|l|l|l|l|l|l|}
\hline & $\begin{array}{l}\text { klik tombol } \\
\text { login }\end{array}$ & atau poli & & \\
\hline
\end{tabular}

\subsubsection{Pengujian Halaman Utama Admin}

Rencana pengujian halaman utama admin yang terdapat pada website puskesmas tanah abang dan puskesmas bukit selabu akan dilakukan berdasarkan tabel berikut ini:

Tabel 2 Pengujian Halaman Utama Admin

\begin{tabular}{|c|c|c|c|c|c|}
\hline No & $\begin{array}{c}\text { Item yang } \\
\text { diuji }\end{array}$ & $\begin{array}{c}\text { Cara } \\
\text { pengujian }\end{array}$ & $\begin{array}{l}\text { Hasil yang } \\
\text { diharapkan }\end{array}$ & $\begin{array}{c}\text { Hasil } \\
\text { pengujian }\end{array}$ & Keterangan \\
\hline 1 & $\begin{array}{l}\text { Halaman } \\
\text { Utama } \\
\text { Admin }\end{array}$ & $\begin{array}{l}\text { Admin } \\
\text { mengklik } \\
\text { menu input } \\
\text { data poli }\end{array}$ & $\begin{array}{l}\text { Menampilkan } \\
\text { halaman } \\
\text { menu input } \\
\text { data poli }\end{array}$ & $\begin{array}{l}\text { Sesuai } \\
\text { harapan }\end{array}$ & Berhasil \\
\hline 2 & $\begin{array}{l}\text { Halaman } \\
\text { Utama } \\
\text { Admin }\end{array}$ & $\begin{array}{l}\text { Admin } \\
\text { mengklik } \\
\text { menu input } \\
\text { data dokter }\end{array}$ & $\begin{array}{l}\text { Menampilkan } \\
\text { halaman } \\
\text { menu input } \\
\text { data dokter }\end{array}$ & $\begin{array}{l}\text { Sesuai } \\
\text { harapan }\end{array}$ & Berhasil \\
\hline 3 & $\begin{array}{l}\text { Halaman } \\
\text { Utama } \\
\text { Admin }\end{array}$ & $\begin{array}{l}\text { Admin } \\
\text { mengklik } \\
\text { menu daftar } \\
\text { dokter }\end{array}$ & $\begin{array}{l}\text { Menampilkan } \\
\text { halaman } \\
\text { menu daftar } \\
\text { dokter }\end{array}$ & $\begin{array}{l}\text { Sesuai } \\
\text { harapan }\end{array}$ & Berhasil \\
\hline 4 & $\begin{array}{l}\text { Halaman } \\
\text { Utama } \\
\text { Admin }\end{array}$ & $\begin{array}{l}\text { Admin } \\
\text { mengklik } \\
\text { menu daftar } \\
\text { poli }\end{array}$ & $\begin{array}{l}\text { Menampilkan } \\
\text { halaman } \\
\text { menu daftar } \\
\text { poli }\end{array}$ & $\begin{array}{l}\text { Sesuai } \\
\text { harapan }\end{array}$ & Berhasil \\
\hline 5 & $\begin{array}{l}\text { Halaman } \\
\text { Utama } \\
\text { Admin }\end{array}$ & $\begin{array}{l}\text { Admin } \\
\text { mengklik } \\
\text { menu } \\
\text { seluruh } \\
\text { pendaftaran }\end{array}$ & $\begin{array}{l}\text { Menampilkan } \\
\text { halaman } \\
\text { menu } \\
\text { seluruh } \\
\text { pendaftaran }\end{array}$ & $\begin{array}{l}\text { Sesuai } \\
\text { harapan }\end{array}$ & Berhasil \\
\hline 6 & $\begin{array}{l}\text { Halaman } \\
\text { Utama } \\
\text { Admin }\end{array}$ & $\begin{array}{l}\text { Admin } \\
\text { mengklik } \\
\text { menu } \\
\text { berdasarkan } \\
\text { poli }\end{array}$ & $\begin{array}{l}\text { Menampilkan } \\
\text { halaman } \\
\text { menu } \\
\text { berdasarkan } \\
\text { poli }\end{array}$ & $\begin{array}{l}\text { Sesuai } \\
\text { harapan }\end{array}$ & Berhasil \\
\hline
\end{tabular}




\section{Journal of Software Engineering Ampera}

Vol. 1, No. 2, June 2021 e-ISSN: 2775-2488

https://journal-computing.org/index.php/journal-sea/index

\begin{tabular}{|l|l|l|l|l|l|}
\hline 7 & Halaman & Admin & Menampilkan & Sesuai & Berhasil \\
& Utama & mengklik & halaman & harapan & \\
& Admin & $\begin{array}{l}\text { menu } \\
\text { periode } \\
\text { pendaftaran }\end{array}$ & $\begin{array}{l}\text { periode } \\
\text { pendaftaran }\end{array}$ & & \\
& & & & \\
\hline
\end{tabular}

\subsubsection{Pengujian Halaman Admin Menu Input Data Poli}

Rencana pengujian halaman admin menu input data poli yang terdapat pada website puskesmas tanah abang dan puskesmas bukit selabu akan dilakukan berdasarkan tabel berikut ini:

Tabel 3 Pengujian Halaman Admin Menu Input Data Poli

\begin{tabular}{|l|l|l|l|l|l|}
\hline No & \multicolumn{1}{|c|}{$\begin{array}{c}\text { Item yang } \\
\text { diuji }\end{array}$} & \multicolumn{1}{c|}{$\begin{array}{c}\text { Cara } \\
\text { pengujian }\end{array}$} & $\begin{array}{c}\text { Hasil yang } \\
\text { diharapkan }\end{array}$ & $\begin{array}{c}\text { Hasil } \\
\text { pengujian }\end{array}$ & Keterangan \\
\hline 1 & $\begin{array}{l}\text { Halaman } \\
\text { admin } \\
\text { menu input } \\
\text { data poli }\end{array}$ & $\begin{array}{l}\text { Admin } \\
\text { mengklik } \\
\text { pada menu } \\
\text { input data } \\
\text { poli }\end{array}$ & $\begin{array}{l}\text { Menampilkan } \\
\text { halaman } \\
\text { menu input } \\
\text { data poli }\end{array}$ & $\begin{array}{l}\text { Sesuai } \\
\text { harapan }\end{array}$ & Berhasil \\
\hline 2 & $\begin{array}{l}\text { Halaman } \\
\text { admin } \\
\text { menu input } \\
\text { data poli }\end{array}$ & $\begin{array}{l}\text { Admin } \\
\text { mengklik } \\
\text { tombol data } \\
\text { baru }\end{array}$ & $\begin{array}{l}\text { Menampilkan } \\
\text { halaman } \\
\text { pendaftaran } \\
\text { poli baru }\end{array}$ & $\begin{array}{l}\text { Sesuai } \\
\text { harapan }\end{array}$ & Berhasil \\
\hline 3 & $\begin{array}{l}\text { Halaman } \\
\text { admin } \\
\text { menu input } \\
\text { data poli }\end{array}$ & $\begin{array}{l}\text { Admin } \\
\text { mengklik } \\
\text { tombol pilih }\end{array}$ & $\begin{array}{l}\text { Menampilkan } \\
\text { halaman edit } \\
\text { data poli }\end{array}$ & $\begin{array}{l}\text { Sesuai } \\
\text { harapan }\end{array}$ & Berhasil \\
\hline 4 & $\begin{array}{l}\text { Halaman } \\
\text { admin } \\
\text { menu input } \\
\text { data poli }\end{array}$ & $\begin{array}{l}\text { Admin } \\
\text { mengklik } \\
\text { tombol user }\end{array}$ & $\begin{array}{l}\text { Menampilkan } \\
\text { halaman edit } \\
\text { user poli }\end{array}$ & $\begin{array}{l}\text { Sesuai } \\
\text { harapan }\end{array}$ & Berhasil \\
\hline
\end{tabular}

\subsubsection{Pengujian Halaman Admin Menu Input Data Dokter}

Rencana pengujian halaman admin menu input data dokter yang terdapat pada website puskesmas tanah abang dan puskesmas bukit selabu akan dilakukan berdasarkan tabel berikut ini: 


\section{Journal of Software Engineering Ampera}

Vol. 1, No. 2, June 2021 e-ISSN: 2775-2488

https://journal-computing.org/index.php/journal-sea/index

Tabel 4 Pengujian Halaman Admin Menu Input Data Dokter

\begin{tabular}{|l|l|l|l|l|l|}
\hline No & $\begin{array}{c}\text { Item yang } \\
\text { diuji }\end{array}$ & \multicolumn{1}{|c|}{$\begin{array}{c}\text { Cara } \\
\text { pengujian }\end{array}$} & $\begin{array}{c}\text { Hasil yang } \\
\text { diharapkan }\end{array}$ & $\begin{array}{c}\text { Hasil } \\
\text { pengujian }\end{array}$ & Keterangan \\
\hline 1 & $\begin{array}{l}\text { Halaman } \\
\text { admin } \\
\text { menu input } \\
\text { data dokter }\end{array}$ & $\begin{array}{l}\text { Admin } \\
\text { mengklik } \\
\text { pada menu } \\
\text { input data } \\
\text { dokter }\end{array}$ & $\begin{array}{l}\text { Menampilkan } \\
\text { halaman } \\
\text { menu input } \\
\text { data dokter }\end{array}$ & $\begin{array}{l}\text { Sesuai } \\
\text { harapan }\end{array}$ & Berhasil \\
\hline 2 & $\begin{array}{l}\text { Halaman } \\
\text { admin } \\
\text { menu input } \\
\text { data dokter }\end{array}$ & $\begin{array}{l}\text { Admin } \\
\text { mengklik } \\
\text { tombol data } \\
\text { baru }\end{array}$ & $\begin{array}{l}\text { Menampilkan } \\
\text { halaman } \\
\text { pendaftaran } \\
\text { dokter baru }\end{array}$ & $\begin{array}{l}\text { Sesuai } \\
\text { harapan }\end{array}$ & Berhasil \\
\hline 3 & $\begin{array}{l}\text { Halaman } \\
\text { admin } \\
\text { menu input } \\
\text { data dokter }\end{array}$ & $\begin{array}{l}\text { Admin } \\
\text { mengkili } \\
\text { tombol pilih }\end{array}$ & $\begin{array}{l}\text { Menampilkan } \\
\text { halaman } \\
\text { edit/hapus } \\
\text { data dokter }\end{array}$ & $\begin{array}{l}\text { Sesuai } \\
\text { harapan }\end{array}$ & Berhasil \\
\hline
\end{tabular}

\subsubsection{Pengujian Halaman Utama Loket}

Rencana pengujian halaman utama loket yang terdapat pada website puskesmas tanah abang dan puskesmas bukit selabu akan dilakukan berdasarkan tabel berikut ini:

Tabel 5 Pengujian Halaman Utama Loket

\begin{tabular}{|l|l|l|l|l|l|}
\hline No & $\begin{array}{c}\text { Item yang } \\
\text { diuji }\end{array}$ & \multicolumn{1}{c|}{$\begin{array}{c}\text { Cara } \\
\text { pengujian }\end{array}$} & $\begin{array}{c}\text { Hasil yang } \\
\text { diharapkan }\end{array}$ & $\begin{array}{c}\text { Hasil } \\
\text { pengujian }\end{array}$ & keterangan \\
\hline 1 & $\begin{array}{l}\text { Halaman } \\
\text { utama loket }\end{array}$ & $\begin{array}{l}\text { User } \\
\text { mengklik } \\
\text { pada menu } \\
\text { input data } \\
\text { pendaftaran }\end{array}$ & $\begin{array}{l}\text { Menampilkan } \\
\text { halaman } \\
\text { menu input } \\
\text { data } \\
\text { pendaftaran }\end{array}$ & $\begin{array}{l}\text { Sesuai } \\
\text { harapan }\end{array}$ & Berhasil \\
\hline 2 & $\begin{array}{l}\text { Halaman } \\
\text { utama loket }\end{array}$ & $\begin{array}{l}\text { User } \\
\text { mengklik } \\
\text { pada menu } \\
\text { seluruh } \\
\text { pendaftaran }\end{array}$ & $\begin{array}{l}\text { Menampilkan } \\
\text { halaman } \\
\text { menu } \\
\text { seluruh } \\
\text { pendaftaran }\end{array}$ & $\begin{array}{l}\text { Sesuai } \\
\text { harapan }\end{array}$ & Berhasil \\
\hline 3 & $\begin{array}{l}\text { Halaman } \\
\text { utama loket }\end{array}$ & $\begin{array}{l}\text { User } \\
\text { mengklik } \\
\text { pada menu } \\
\text { berdasarkan }\end{array}$ & $\begin{array}{l}\text { Menampilkan } \\
\text { halaman } \\
\text { menu } \\
\text { berdasarkan }\end{array}$ & $\begin{array}{l}\text { Sesuai } \\
\text { harapan }\end{array}$ & Berhasil \\
& & & & \\
\end{tabular}




\section{Journal of Software Engineering Ampera}

Vol. 1, No. 2, June 2021 e-ISSN: 2775-2488

https://journal-computing.org/index.php/journal-sea/index

\begin{tabular}{|l|l|l|l|l|l|}
\hline & & poli & poli & \\
\hline 4 & $\begin{array}{l}\text { Halaman } \\
\text { utama loket }\end{array}$ & $\begin{array}{l}\text { User } \\
\text { mengklik } \\
\text { pada menu } \\
\text { periode } \\
\text { pendaftaran }\end{array}$ & $\begin{array}{l}\text { Menampilkan } \\
\text { halaman } \\
\text { menu } \\
\text { periode } \\
\text { pendaftaran }\end{array}$ & $\begin{array}{l}\text { Sesuai } \\
\text { harapan }\end{array}$ & Berhasil \\
& & & \\
\end{tabular}

\subsubsection{Pengujian Halaman Loket Menu Input Data Pendaftaran}

Rencana pengujian halaman loket menu input data pendaftaran yang terdapat pada website puskesmas tanah abang dan puskesmas bukit selabu akan dilakukan berdasarkan tabel berikut ini:

Tabel 6 Pengujian Halaman Loket Menu Input Data Pendaftaran

\begin{tabular}{|l|l|l|l|l|l|}
\hline No & $\begin{array}{c}\text { Item yang } \\
\text { diuji }\end{array}$ & \multicolumn{1}{|c|}{$\begin{array}{c}\text { Cara } \\
\text { pengujian }\end{array}$} & $\begin{array}{c}\text { Hasil yang } \\
\text { diharapkan }\end{array}$ & $\begin{array}{c}\text { Hasil } \\
\text { pengujian }\end{array}$ & keterangan \\
\hline 1 & $\begin{array}{l}\text { Halaman } \\
\text { loket menu } \\
\text { input data } \\
\text { pendaftaran }\end{array}$ & $\begin{array}{l}\text { User } \\
\text { mengklik } \\
\text { pada menu } \\
\text { input data } \\
\text { pendaftaran }\end{array}$ & $\begin{array}{l}\text { Menampilkan } \\
\text { halaman } \\
\text { menu input } \\
\text { data } \\
\text { pendaftaran }\end{array}$ & $\begin{array}{l}\text { Sesuai } \\
\text { harapan }\end{array}$ & Berhasil \\
\hline 2 & $\begin{array}{l}\text { Halaman } \\
\text { loket menu } \\
\text { input data } \\
\text { pendaftaran }\end{array}$ & $\begin{array}{l}\text { User } \\
\text { mengklik } \\
\text { tombol } \\
\text { pendaftaran } \\
\text { baru }\end{array}$ & $\begin{array}{l}\text { Menampilkan } \\
\text { halaman } \\
\text { pendaftaran } \\
\text { baru }\end{array}$ & $\begin{array}{l}\text { Sesuai } \\
\text { harapan }\end{array}$ & Berhasil \\
\hline 3 & $\begin{array}{l}\text { Halaman } \\
\text { loket menu } \\
\text { input data } \\
\text { pendaftaran }\end{array}$ & $\begin{array}{l}\text { User } \\
\text { mengklik } \\
\text { tombol pilih }\end{array}$ & $\begin{array}{l}\text { Menampilkan } \\
\text { halaman data } \\
\text { pasien yang } \\
\text { dipilih }\end{array}$ & $\begin{array}{l}\text { Sesuai } \\
\text { harapan }\end{array}$ & Berhasil \\
\hline
\end{tabular}

\subsubsection{Pengujian Halaman Utama Poli}

Rencana pengujian halaman utama poli yang terdapat pada website puskesmas tanah abang dan puskesmas bukit selabu akan dilakukan berdasarkan tabel berikut ini: 


\section{Journal of Software Engineering Ampera}

Vol. 1, No. 2, June 2021 e-ISSN: 2775-2488

https://journal-computing.org/index.php/journal-sea/index

Tabel 7 Pengujian Halaman Menu Utama Poli

\begin{tabular}{|l|l|l|l|l|l|}
\hline No & \multicolumn{1}{|c|}{$\begin{array}{c}\text { Item yang } \\
\text { diuji }\end{array}$} & \multicolumn{1}{c|}{$\begin{array}{c}\text { Cara } \\
\text { pengujian }\end{array}$} & $\begin{array}{c}\text { Hasil yang } \\
\text { diharapkan }\end{array}$ & $\begin{array}{c}\text { Hasil } \\
\text { pengujian }\end{array}$ & Keterangan \\
\hline 1 & $\begin{array}{l}\text { Halaman } \\
\text { menu } \\
\text { utama poli }\end{array}$ & $\begin{array}{l}\text { User } \\
\text { mengklik } \\
\text { pada menu } \\
\text { input } \\
\text { konsultasi }\end{array}$ & $\begin{array}{l}\text { Menampilkan } \\
\text { halaman } \\
\text { menu input } \\
\text { konsultasi }\end{array}$ & $\begin{array}{l}\text { Sesuai } \\
\text { harapan }\end{array}$ & Berhasil \\
\hline 2 & $\begin{array}{l}\text { Halaman } \\
\text { menu } \\
\text { utama poli }\end{array}$ & $\begin{array}{l}\text { User } \\
\text { mengklik } \\
\text { pada menu } \\
\text { seluruh } \\
\text { pendaftaran }\end{array}$ & $\begin{array}{l}\text { Menampilkan } \\
\text { halaman } \\
\text { menu } \\
\text { seluruh } \\
\text { pendaftaran }\end{array}$ & $\begin{array}{l}\text { Sesuai } \\
\text { harapan }\end{array}$ & Berhasil \\
\hline 3 & $\begin{array}{l}\text { Halaman } \\
\text { menu } \\
\text { utama poli }\end{array}$ & $\begin{array}{l}\text { User } \\
\text { mengklik } \\
\text { pada menu } \\
\text { periode } \\
\text { pendaftaran }\end{array}$ & $\begin{array}{l}\text { Menampilkan } \\
\text { halaman } \\
\text { menu } \\
\text { periode } \\
\text { pendaftaran }\end{array}$ & $\begin{array}{l}\text { Sesuai } \\
\text { harapan }\end{array}$ & Berhasil \\
\hline
\end{tabular}

\subsubsection{Pengujian Halaman Poli Menu Input Konsultasi}

Rencana pengujian halaman poli menu input konsultasi yang terdapat pada website puskesmas tanah abang dan puskesmas bukit selabu akan dilakukan berdasarkan tabel berikut ini:

Tabel 8 Pengujian Halaman Poli Menu Input Konsultasi

\begin{tabular}{|l|l|l|l|l|l|}
\hline No & $\begin{array}{c}\text { Item yang } \\
\text { diuji }\end{array}$ & \multicolumn{1}{|c|}{$\begin{array}{c}\text { Cara } \\
\text { pengujian }\end{array}$} & $\begin{array}{c}\text { Hasil yang } \\
\text { diharapkan }\end{array}$ & $\begin{array}{c}\text { Hasil } \\
\text { pengujian }\end{array}$ & Keterangan \\
\hline 1 & $\begin{array}{l}\text { Halaman } \\
\text { poli menu } \\
\text { input } \\
\text { konsultasi }\end{array}$ & $\begin{array}{l}\text { User } \\
\text { mengklik } \\
\text { pada menu } \\
\text { input } \\
\text { konsultasi }\end{array}$ & $\begin{array}{l}\text { Menampilkan } \\
\text { halaman } \\
\text { menu input } \\
\text { konsultasi }\end{array}$ & $\begin{array}{l}\text { Sesuai } \\
\text { harapan }\end{array}$ & Berhasil \\
\hline 2 & $\begin{array}{l}\text { Halaman } \\
\text { menu } \\
\text { utama poli }\end{array}$ & $\begin{array}{l}\text { User } \\
\text { mengklik } \\
\text { tombol pilih }\end{array}$ & $\begin{array}{l}\text { Menampilkan } \\
\text { halaman } \\
\text { biodata } \\
\text { pasien, } \\
\text { rekam medik }\end{array}$ & $\begin{array}{l}\text { Sesuai } \\
\text { harapan }\end{array}$ & Berhasil \\
\hline
\end{tabular}




\section{Journal of Software Engineering Ampera}

Vol. 1, No. 2, June 2021 e-ISSN: 2775-2488

https://journal-computing.org/index.php/journal-sea/index

\begin{tabular}{|l|l|l|l|l|l|}
\hline & & dan konsul & & \\
\end{tabular}

\subsubsection{Pengujian Halaman Pencarian Rekam Medis}

Rencana pengujian halaman poli pada menu pencarian rekam medis pasien dilakukan dengan cara masuk kedalam halaman poli, kemudian pilih menu konsultasi, selanjut nya pilih pasien yang mendaftar untuk berobat, akan ada tiga menu pilihan yang salah satunya adalah rekam medis, silahkan pilih puskesmas yang diinginkan untuk mencari rekam medis pasien di puskesmas tersebut kemudian klik tampilkan, dan yang terakhir kita tinggal menulis nama pasien pada menu pencarian nama maka data rekam medis pasien yang dicari akan muncul. Berikut adalah tabel pengujian pada halaman rekam medis yang dilakukan di website puskesmas tanah abang dan puskesmas batanghari leko:

Tabel 9 Pengujian Halaman Rekam Medis

\begin{tabular}{|c|c|c|c|c|c|}
\hline No & $\begin{array}{c}\text { Item yang } \\
\text { diuji }\end{array}$ & Cara pengujian & $\begin{array}{l}\text { Hasil yang } \\
\text { diharapkan }\end{array}$ & $\begin{array}{c}\text { Hasil } \\
\text { pengujian }\end{array}$ & Keterangan \\
\hline 1 & $\begin{array}{l}\text { Halaman } \\
\text { Rekam } \\
\text { Medis }\end{array}$ & $\begin{array}{l}\text { User memilih } \\
\text { puskesmas dan } \\
\text { klik tampilkan, } \\
\text { kemudian tullis } \\
\text { nama pasien } \\
\text { yang dicari pada } \\
\text { menu pencarian } \\
\text { nama }\end{array}$ & $\begin{array}{l}\text { Menampilkan } \\
\text { rekam medis } \\
\text { pasien yang } \\
\text { dicari }\end{array}$ & $\begin{array}{l}\text { Sesuai } \\
\text { harapan }\end{array}$ & Berhasil \\
\hline
\end{tabular}

\section{KESIMPULAN}

Berdasarkan hasil dari penelitian yang dilakukan pada sistem web service antar puskesmas tanah abang dan puskesmas bukit selabu, penulis dapat mengambil kesimpulan bahwa simulasi website dan web service pada puskesmas tanah abang dan puskesmas bukit selabu telah selesai dan berhasil dibangun serta telah melalui tahapan pengujian sistem dengan menggunakan metode pengujian blackbox testing dan dari hasil pengujian tersebut penulis juga mendapaatkan hasil yang sesuai dengan rencana yang telah ditentukan, pada akhirnya sistem web service bisa berjalan sesuai dengan yang diharapkan. Sistem web service ini juga bisa sangat membantu 


\section{Journal of Software Engineering Ampera}

Vol. 1, No. 2, June 2021 e-ISSN: 2775-2488

https://journal-computing.org/index.php/journal-sea/index

kinerja dari puskesmas tersebut dimana kinerja dari puskesmas akan lebih cepat dan lebih efisien serta lebih produktif.

\section{DAFTAR PUSTAKA}

[1] Santoso, N. and Amalia, F. (2019) 'Implementasi Web Service Pada Sistem Rekam Medis Terpusat', p. 6.

[2] Herliana, A. and Rasyid, P. M. (2016) 'Sistem Informasi Monitoring Pengembangan Software Pada Tahap Development Berbasis Web', Jurnal Informatika, p. 10.

[3] Rizal, R. and Rahmatulloh, A. (2019) 'Restful Web Service Untuk Integrasi Sistem Akademik Dan Perpustakaan Universitas Perjuangan', Jurnal Ilmiah Informatika, 7(01), p. 54. doi: 10.33884/jif.v7i01.1004.

[4] Yusuf, R. (2015) 'Aggregator Otomatis Pencari Produk Dengan Pemberitahuan Melalui Surel Menggunakan Fungsi CURL', Jurnal Teknik Informatika, 8(1). doi: 10.15408/jti.v8i1.1936.

[5] Kasaedja, B. A., Sengkey, R. and Lantang, O. A. (2014) 'Rancang Bangun Web Service Perpustakaan Universitas Sam Ratulangi', p. 13.

[6] "Pengenalan JSON," JSON, [Online]. Available: www.json.org/jsonid.html. [Accessed 1212 2020].

[7] Andriana, Diana (2003) 'Pengenalan Pemrograman E-Commerce dengan PHP dan MySQL'. 